than as a circulating hormone involved in cardiovascular homeostasis. Thus, measurement of plasma CNP levels and studies involving systemic infusions of CNP may have only a limited role in clarifying its physiological significance.

This research programme was supported by the Scottish Hospital Endowments Research Trust.

1 Komatsu Y, Nakao K, Suga S, Ogawa Y, Mukoyama M, Arai $\mathrm{H}$, et al. C-type natriuretic peptide in rats and humans. Endocrinology 1991;129:1104-6.

2 Stingo AJ, Clavell AL, Heublein DM, Wei C, Pittelkow MR, Burnett JC. Presence of C-type natriuretic peptide in cultured human endothelial cells and plasma. $A m \mathcal{F}$ in cultured human endothe

3 Suga S, Nakao K, Itoh H, Komatsu Y, Hama N, Imura H Endothelial production of C-type natriuretic peptide and its marked augmentation by transforming growth facto B. $\mathcal{F}$ Clin Invest 1993;90:1145-9.
4 Koller KJ, Lowe DG, Bennett GL, Minamino N, Kangawa $\mathrm{K}$, Matsuo $\mathrm{H}$, et al. Selective activation of the B-natriuretic peptide receptor by C-type natriuretic peptide (CNP) Science 1991;252:120-3.

5 Stingo AJ, Clavell AL, Aarhus LL, Burnett JC. Cardiovascular and renal actions of $\mathrm{C}$-type natriuretic peptide. Am $\mathcal{}$ Physiol 1992;262:H308-12.

6 Wei CM, Heublein DM, Perrella MA, Lerman A, Rodeheffer RJ, McGregor CGA, et al. Natriuretic peptide ystem in human heart failure. Circulation 1993;88:1004-9.

7 Lang CC, Coutie WS, Struthers AD, Dhillon DP, Winter JH Lipworth BJ. Elevated levels of brain natriuretic peptide in acute hypoxaemic chronic obstructive pulmonary disease. Clin Sci 1992;83:529-33.

8 Burnett JC, Kao PC, Hu DC, Heger D, Heublein D, Granger J, et al. Atrial natriuretic peptide elevation in congestive heart failure in the human. Science $1986 ; 231$ : 1145-7.

9 Cargill RI, Coutie WJ, Lipworth BJ. The effects of angiotensin II on circulating levels of natriuretic peptides. Br f Clin Pharmacol 1994;38:139-42.

10 Baertschi A, Adams JM, Sullivan MP. Acute hypoxaemia stimulates atrial natriuretic factor secretion in vivo. $\mathrm{Am} \mathcal{F}$ Physiol 1988;255:H295-300.

\title{
Effect of exercise on the nasal transmucosal potential difference in patients with cystic fibrosis and normal subjects
}

\author{
S Alsuwaidan, A Li Wan Po, G Morrison, A Redmond, J A Dodge, J McElnay, \\ E Stewart, C F Stanford
}

\section{School of Pharmacy, The Queen's University of Belfast \\ $S$ Alsuwaidan \\ A Li Wan Po \\ J McElnay}

Royal Belfast Hospital for Sick Children

G Morrison

A Redmond

J A Dodge

Royal Victoria

Hospital

E Stewart

C F Stanford

Belfast, UK

Reprint requests to: Dr C F Stanford,

Department of Medicine,

King Khalid National Guard

Hospital,

Jeddah 21423, PO Box

516

Saudi Arabia.

Received 22 January 1992

Returned to authors

10 April 1992

Revised version received

7 June 1994

Accepted for publication

9 September 1994

Mean (SE) effects of exercise on the nasal transmucosal potential difference in patients with cystic fibrosis and controls

\begin{tabular}{lllll}
\hline & $\begin{array}{l}\text { Before } \\
\text { exercise }\end{array}$ & $\begin{array}{l}\text { After } \\
\text { exercise }\end{array}$ & $\begin{array}{l}\text { Greatest change } \\
\text { after exercise }\end{array}$ & Recovery \\
\hline Cystic fibrosis $(\mathrm{n}=7)$ & $-27 \cdot 6_{*}^{(5 \cdot 8)}$ & $-17 \cdot 7(5 \cdot 2) \dagger$ & $-16 \cdot 6(5 \cdot 5) \dagger$ & $-32 \cdot 6(5 \cdot 9)$ \\
Controls $(\mathrm{n}=7)$ & $-12 \cdot 0^{*}(2 \cdot 1)$ & $-19 \cdot 8(2 \cdot 4) \dagger$ & $-22 \cdot 1(3 \cdot 2) \dagger$ & $-17 \cdot 2(2 \cdot 8)$ \\
\hline
\end{tabular}

* Differences within columns $(p<0.05)$

$\dagger$ Differences between resting and subsequent values within rows $(p<0.05)$. the results for the patients with cystic fibrosis had returned to their resting values. Conclusions - Exercise reduces the abnormally high resting values for nasal TPD in patients with cystic fibrosis. Elucidation of the mechanism for this change may help to produce functional improvement for patients with this disease.

(Thorax 1994;49:1249-1250)

Cystic fibrosis is characterised by an increase in thick mucous secretions. A defective transmembrane regulator for chloride transport in epithelial cells, unable to open under the influence of cyclic AMP, has been described. ${ }^{1}$ Respiratory epithelial cells from patients with cystic fibrosis also have a high sodium absorption from the mucosal surface which causes a more negative transmucosal potential difference (TPD) than in controls. ${ }^{2}$

Exercise causes an increase in nasal secretion in normal subjects. ${ }^{3}$ TPD also increases in normal subjects during exercise, a change probably related to the increase in secretion. ${ }^{4}$ The current study was performed to see if the nasal TPD behaved in the same way during exercise in patients with cystic fibrosis and healthy subjects.

\section{Methods}

Seven patients with cystic fibrosis (four men) aged 9-24 years and seven age and gender matched healthy controls volunteered for the 


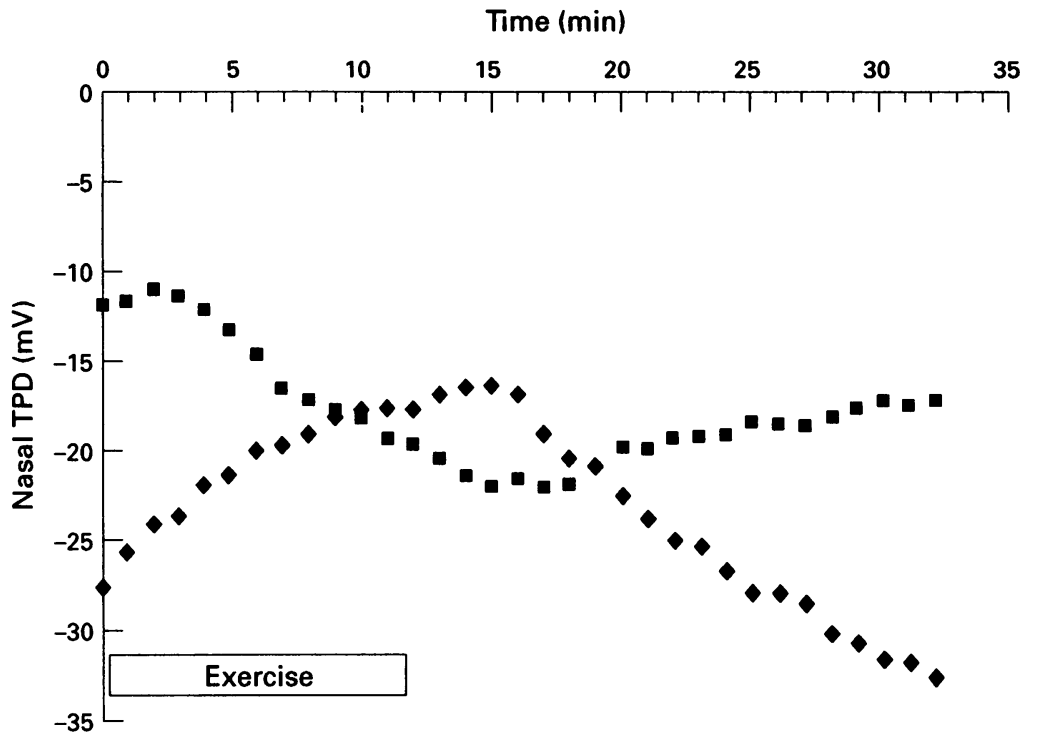

Effect of 12 minutes of exercise on the mean nasal transmucosal potential difference $(T P D)$ in seven patients with cystic fibrosis $(\diamond)$ and seven healthy controls ( $\square$ ).

study which was passed by the ethical committee of the Queen's University, Belfast. The mean Schwachman-Kulczycki clinical score of the patients was 64 (range 34-92).

Exercise was performed for 12 minutes on a bicycle and set at a work level to achieve $80 \%$ of their predicted maximum heart rate.

The nasal TPD was measured using a soft rubber catheter as the exploring electrode, the reference electrode being placed over an area of abraded skin. ${ }^{5}$ The nasal electrode was placed on the floor of the nasal cavity and kept in place at the site of maximum negative potential difference by tape at the anterior nares. The catheter well was kept filled with electrolyte gel throughout the study. The mean potential difference values over the last $10 \mathrm{sec}-$ onds of each minute were computed using an Amstrad computer with an SIEM-3 program. All subjects rested for 30 minutes before the study and the catheter was inserted 10 minutes before exercise began. Twelve minutes of exercise were followed by 20 minutes of rest.

Statistical analysis was by paired $t$ tesing, a probability level of $p<0.05$ being accepted as a statistically significant result.

\section{Results}

The results are as shown in the table. There was a significant difference between the resting nasal TPD for the two groups of subjects, the patients with cystic fibrosis being more negative. During exercise (figure) the values for the patients with cystic fibrosis became relatively more positive and at the end of exercise these were significantly different from the resting values $(p<0.05)$. At the end of the rest period the values increased to become more negative and they were not significantly different from the pre-exercise values. In the control subjects, however, the nasal TPD increased to become more negative with exercise. This increase was significant $(p<0.05)$ and, at that stage, was not significantly different from that for the patients with cystic fibrosis. After exercise the control values diminished towards the resting ones.

\section{Discussion}

The resting values for nasal TPD for the patients with cystic fibrosis and the controls were significantly different in this study and were within the range of other published values. ${ }^{35}$ The alteration in the potential difference with exercise was in the opposite direction in the two groups. Within the two groups and in previous studies there was no evidence of reversion towards the mean in subjects whose resting values were either high or low for the group. We therefore feel that this difference between the groups is a real observation. Although the mechanism of the change in potential difference may be different in the two groups, the actual potential difference was significantly different at the end of exercise.

In exercise increased nasal secretion is needed to humidify the air. Much of this increase in secretion is by parasympathetic nerve stimulation since it can be blocked by ipratropium. ${ }^{6}$ Since methacholine also increases the nasal TPD, ${ }^{4}$ it is probable that an increased secretion of chloride contributes to the greater negative potential in healthy subjects. In patients with cystic fibrosis, however, the nasal TPD becomes less negative. If chloride channels cannot open properly in the respiratory mucosa, then one would not expect TPD to increase with exercise in cystic fibrosis. Patients with this disease do have a problem with increasing the humidification of dry air, ${ }^{7}$ but the clinical observation that they can produce clinical secretions remains. It is therefore possible that the more positive TPD during exercise results from a decrease in their exaggerated sodium ion absorption, especially since the sodium channel blocker, amiloride, can cause this change at rest. ${ }^{8}$ The deficient chloride channels can be made to open at rest when cells are stimulated by ATP or UTP following amiloride blockade. ${ }^{8}$ Whether or not purinergic receptors are active during exercise in patients with cystic fibrosis or control subjects is not known.

Elucidation of the mechanism of mucosal TPD reduction during exercise in patients with cystic fibrosis may provide a therapeutic option for the treatment of this disease. Dr E Stewart was in receipt of an Allen and Hanburys Research
Fellowship. Dr G Morrison was in receipt of a Cystic Fibrosis Fellowship. Dr G Morrison was in
Foundation Research Fellowship.

$1 \mathrm{Li} \mathrm{M}$, McCann JD, Liedtke CM, Nairn AC, Greengard P, Welsh MJ. Cyclic AMP-dependent protein kinase affects chloride channels in normal but not cystic fibrosis airway epithelium. Nature 1988;331:358-60.

2 Knowles MR, Gatzy JT, Boucher RC. Increased bioelectric potential differences across respiratory epithelia in cystic fibpotential differences across respiratory epit

3 Stanford CF, Stanford RC. Exercise induced rhinorrhea (athStanford CF, Stanford RC. Exercise
lete's nose). $B M 7$ 1988;297:660.

4 Stewart EJ, Cinnamon DM, Nicholls DP, Stanford CF. The

Stewart EJ, Cinnamon DM, Nicholls DP, Stanford CF. The
effect of methacholine on nasal potential difference. Rhinology effect of methach

5 Alton EWFW, Hay JG, Munro C, Geddes DM. Measurement Alton EWFW, Hay JG, Munro C, Geddes DM. Measurement
of nasal potential difference in adult cystic fibrosis, Young's syndrome and bronchiectasis. Thorax 1987;42:815-7.

6 Harris W, Giebaly K, Adair C, Adair C, Al Suwaidan S, Nicholls DP, Stanford CF. The parasympathetic system in exercise induced rhinorrhea. Rhinology 1992;30:21-3.

7 Primiand FP, Saidel GM, Montagu FW, Kruse KL, Green CG, Horowitz JG. Water vapour and temperature dynamics in the upper airways of normal and CF subjects. Eur Respir f 1988;1:407-14

8 Knowles MR, Clarke LL, Boucher RC. Activation by extracellular nucleotides of chloride secretion in the airway epi533-8. 